\section{Australian Journal of \\ Crop Science}

AJCS 14(01):85-91 (2020)

doi: 10.21475/ajcs.20.14.01.p1891
AJCS

ISSN:1835-2707

\title{
Mixed production of Alexandergrass and sorghum under nitrogen fertilization and grazing intensities
}

\author{
André Brugnara Soares*1, Marcieli Maccari², Carine Lisete Glienke ${ }^{3}$, Tangriani Simioni Assmann ${ }^{1}$, Marcos \\ Antonio de Bortolli ${ }^{1}$, Denise Adelaide Gomes Elejalde ${ }^{1}$, Regis Luis Missio ${ }^{1}$
}

\author{
${ }^{1}$ Technological Federal University of Paraná (UTFPR), Brazil \\ ${ }^{2}$ West Santa Catarina University (UNOESC), Brazil \\ ${ }^{3}$ Federal University of Santa Catarina (UFSC), Brazil
}

*Corresponding author: soares@utfpr.edu.br

\begin{abstract}
Annual pasture specie are used in southern Brazil to supply forage in the fall and spring when major forage species have their productivity diminished. Forage sorghum (Sorghum bicolor, (L.) Moench) is a suitable option that has been adopted by farmers due to its high quality as forage. It has been observed that in areas where forage sorghum is cultivated, alexandergrass (Urochloa plantaginea) usually appear as a spontaneous specie. The aim of this study was to observe the effect of two grazing intensities ( 30 and $60 \mathrm{~cm}$ of sward height) and two nitrogen fertilization levels ( 0 and $200 \mathrm{~kg} \mathrm{~N} \mathrm{ha}^{-1}$ ) on the quantity (forage mass), quality (CP, ADF, NDF, Lignin, Hemicellulose, Cellulose) and morphological components (stem, leaves, senesced material) of sorghum-alexandergrass mixed pasture grazed by beef cattle. Treatments were arranged in a completed randomized block design with three replications in a $2 \times 2$ factorial scheme. Forage mass was increased during the evaluation period. In the first period, production was 4,022 kg and it reached $5,233 \mathrm{~kg} \mathrm{DM} \mathrm{ha}^{-1}$ in the third period. Treatments did not affect AG-sorghum mixed pasture botanical profile or quality. It was observed that Sorghum lowered its contribution from $63.4 \%$ in the first evaluation period to $21.5 \%$ in the third. In contrast, Alexandregrass (AG), contribution increased from 17.9 to $52.7 \%$ throughout the evaluation periods. Therefore, the addition of Alexandergrass to a planted sorghum pasture is encouraged because it can extend the grazing period into the fall by prolonging the pasture favorable sward structure and nutritive value.
\end{abstract}

Keywords: Botanical composition; Structural composition; Sorghum bicolor; Urochloa plantaginea.

Abbreviations: ADF_acid detergent fiber; AG_Alexandregrass; CP_crude protein; DM_dry matter; NDF_neutral detergent fiber.

Introduction

Annual pasture species are used in high-input intensive grazing management systems in southern Brazil. On top of their high forage quality, they supply biomass in the fall and spring when major forage species have their productivity are diminished. Forage production and accumulation is affected by genetic, soil and climate factors (i.e. temperature, photoperiod, water availability and nutrients). Among the macronutrients, nitrogen is highlighted due to its presence on proteins, enzymes, phytocromes, coenzymes, nucleic acids (DNA and RNA), nitrogenous basis as well on chlorophyll and phytohormones. Forage sorghum (Sorghum bicolor, (L.) Moench.) is a suitable option that has been adopted by farmers due to its high forage production potential, high nutritive value and drought tolerance. It has been observed that in areas where forage sorghum is cultivated, volunteer Alexandergrass (AG) (Urochloa plantaginea) is common, as it is on row crops nearby (mainly corn and soybeans). Alexandergrass is considered and managed similar to a weed, not only on row crops but also on forage fields. However, its excellent tillering and forage accumulation characteristics (Martins et al., 2000; Restle et al., 2002; Sartor et al., 2011; Costa et al., 2011; Menezes et al., 2014; Mezzalira et al., 2014) suggest that managing volunteer Alexandergrass as a forage species can be a viable alternative. Recent research (Oliveira et al., 2018) supports the practice by generating guidelines for Alexandergrass management through herbicide application. Using volunteer AG on cultivated sorghum fields in integrated crop-livestock systems can be a viable low-cost alternative and it will allow longer pasture period of utilization. Annual grasses has a short cycle of utilization characterized by fast structural changes of high magnitude, while a spontaneous grass like AG has a more longer period of utilization because its growth patterns are different.

Nitrogen fertilization and sward height management influence forage accumulation and nutrient usage efficiency. Due to heterogeneity in grazed swards its structure is changed along time. Sward structure impacts animal movement and 
distribution, as well as ingestive behavior and daily intake (Mezzalira et al., 2014; Martini et al., 2017). Nitrogen fertilization also can improve dry matter accumulation rate, forage allowance and crude protein level of AG pasture (Martins et al., 2000). The correct utilization of grazing intensity and pasture management can provide high levels of animal production on sorghum or AG pastures (Restle et al., 2002), both forage species studied separately.

Based on the structure and composition of swards it is possible to infer the nutrient intake of grazing animals. The current study shed a light on the understanding of relationships of these variables. The literature on mixed summer pasture where one of the species is volunteer is also scarce. It is hypothesized that nitrogen fertilization and sward height management will support greater plant structure and botanical components heterogeneity, which in turn, will affect the bromatological composition of the pasture. To the best of our knowledge there is no published literature evaluating both treatments and their possible interactions in sorghum and AG mixed pasture. The objective of the present research was to assess the botanical, chemical and structural composition of SorghumAlexandergrass mixed pastures under grazing heights and nitrogen fertilization levels.

\section{Results and Discussion}

\section{Forage production}

The imposed grazing pressure through the put-and-take method was effective to establish the contrasting canopy heights, where a $43 \mathrm{~cm}$ was achieved for the smaller grazing height $(30 \mathrm{~cm}$ was the target) and $64 \mathrm{~cm}$ for the taller height (60 $\mathrm{cm}$ was the target) to represent the treatments.

Total area application of nitrogen ( $\left.200 \mathrm{~kg} \mathrm{ha}^{-1}\right)$ had no effect on the morphological parameters of the mixed pasture. Even though, grasses like sorghum are responsive to nitrogen application. It is likely that suppling the high level of soil organic matter at sowing and the $42.4 \mathrm{~kg} \mathrm{~N} \mathrm{ha}^{-1}$ provided adequate nitrogen to the pasture throughout the experimental period compared to control (no nitrogen fertilization). It is emphasized that prior to this experiment, the area was cultivated with pinto beans, a crop that is known to produce post-harvest residue with low $\mathrm{C} / \mathrm{N}$ ratio and fast decomposition rates, making the residue nitrogen rapidly available to the studied pasture. We hypothesize that the sorghum pasture had its nitrogen demand met during all development stages.

The evaluation period was the factor that affected the major number of variables linked to forage production (Table 1). Forage mass was affected by grazing height and evaluation period. No significant interaction was observed for the three factors (grazing heights, nitrogen fertilization levels, and evaluation period). Under the higher grazing height $(60 \mathrm{~cm})$, forage mass was recorded at 4,896 $\mathrm{kg} \mathrm{DM} \mathrm{ha}^{-1}$ and for the more severe defoliation treatment $(30 \mathrm{~cm})$ the forage mass was observed at 4,299 $\mathrm{kg} \mathrm{DM} \mathrm{ha}^{-1}$. Nevertheless, it is important to note that forage mass was increased $(P<0.05)$ during the evaluation period, whereas it was $4,022 \mathrm{~kg}$ during the first period and reached 5,233 $\mathrm{kg} \mathrm{DM} \mathrm{ha}^{-1}$ in the third, with total amplitude of $1,211 \mathrm{~kg} \mathrm{DM} \mathrm{ha}^{-1}$ (Fig. 1). On the other hand, the average canopy height was inversely proportional to evaluation period $(59.3,58.5,43.1 \mathrm{~cm})$. Note that the lowest height was observed in the third period, when the highest values for forage mass were recorded.

Like observed in this study, Roman et al. (2008) also found lower forage mass during the early stages of pearl millet grazing. The researchers suggested that higher forage mass later in the research period was a consequence of tillering, which resulted in a denser sward. Restle et al. (2002) in a similar study on sorghum, reached 1,389 of $\mathrm{kg} \mathrm{ha}^{-1}$ green weight, while in this study we achieved $1,675 \mathrm{~kg} \mathrm{ha}^{-1}$ green weight.

Post-grazing tillering is promoted by the increased quantity of solar radiation incidence at the bottom sward strata and the change in its quality (infrared/red light ratio) as pointed out by Robson et al. (1988). On top of providing adequate feed to grazing animals, the high forage mass observed in this study also promoted adequate soil cover, softened the effects of weather variation and animal trampling. AG volunteer presence supported high forage mass levels from the beginning to the end of the study period.

Sorghum plants reached reproductive stage approximately 113 days after sowing, which was accompanied by lower leaf lamina quantity and stem elongation. Therefore, AG preponderance in the sward mass started to be noticed. The reason might be that light reached the topsoil layer and aided seed germination, given that it is a positive photoblastic species and opportunistic for filling empty sward spaces.

Sorghum and AG do not differ considerably in relation to forage accumulation and nutritive value (Restle et al., 2002). In grain production areas, AG is considered a competitive weed. On the other hand, it shows potential as a forage due to its excellent yield levels, nutritive value, proliferous seed production habit, and fast growth habit that eliminate other species from the habitat. Its forage potential was already suggested by earlier research (Adami et al., 2010; Sartor et al., 2011) as well as an herbicide management guideline as part of a crop-livestock system (Oliveira et al., 2018).

\section{Botanical and structural components}

It was observed that sorghum had its contribution lowered from $63.4 \%$ in the first evaluation period to $21.5 \%$ in the third. Meanwhile, AG increased from 17.9 to $52.7 \%$ throughout the evaluation periods (Table 3). Other species and senesced material did not fluctuate significantly $(P<0.05)$.

The AG increases its presence in the mixed sward while senesced material is kept constant along the grazing season. It demonstrates the good opportunity that the mix cultivation offers. It can supply a nutritive diet that does not change as the season progresses.

Botanical composition changes were associated with structural changes in the sward. In the first evaluation period, sorghum participation was significant in all strata and sorghum leaves occupied the higher sward strata $(>30 \mathrm{~cm})$. Mezzalira et al. 
Table 1. Significance level for sources of variation (grazing height, nitrogen fertilization rate and evaluation period) and their interaction with dry matter (DM, \%), forage mass ( $\left.\mathrm{kg} \mathrm{ha}^{-1}\right)$, Sorghum (\%), Sorghum leaf (\%), Sorghum stem (\%), Alexandergrass (\%), senesced material(\%), other species (\%), crude protein (CP), neutral detergent fiber (NDF), acid detergent fiber (ADF), lignin, cellulose and hemicellulose.

\begin{tabular}{|c|c|c|c|c|c|c|c|}
\hline Variables & Hgt & $\mathrm{N}$ & Alt*N & Per & Per*Alt & Per*N & Per*N*Alt \\
\hline Forage Mass & 0.0473 & ns & ns & 0.0082 & ns & ns & ns \\
\hline Sorghum (\%) & ns & ns & ns & 0.0001 & ns & ns & ns \\
\hline Sorghum leaf (\%) & ns & ns & ns & 0.0002 & & & \\
\hline Sorghum stem (\%) & 0.0002 & ns & ns & 0.0011 & 0.0034 & ns & ns \\
\hline Alexandergrass (\%) & 0.0053 & ns & ns & $<0.0001$ & ns & ns & ns \\
\hline Senesced material (\%) & ns & ns & ns & ns & 0.0134 & ns & ns \\
\hline Other species (\%) & ns & ns & ns & ns & ns & ns & ns \\
\hline CP (\%) & ns & ns & ns & ns & ns & ns & ns \\
\hline NDF (\%) & ns & ns & ns & 0.0059 & ns & ns & ns \\
\hline ADF (\%) & ns & ns & ns & ns & ns & ns & ns \\
\hline Lignin (\%) & ns & ns & ns & 0.0011 & ns & & ns \\
\hline Cellulose (\%) & ns & ns & ns & ns & ns & ns & ns \\
\hline Hemicellulose & ns & ns & ns & ns & ns & ns & ns \\
\hline
\end{tabular}

Hgt: sward height; $\mathrm{N}$ : nitrogen fertilization level; Per: evaluation period and ns: non-significant $(\mathrm{P}>0.05)$.

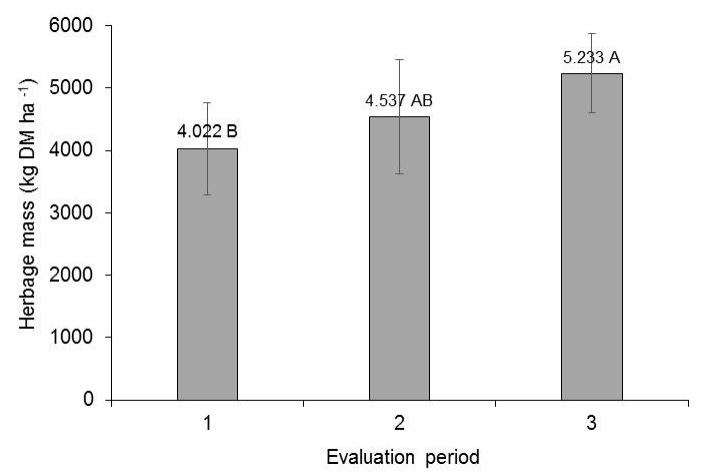

Fig 1. Forage mass $\left(\mathrm{kg} \mathrm{ha}^{-1}\right)$ according to evaluation period (1: February 8 to March 1, 2013; 2: March 1 to March 22, 2013; and 3: March 22 to April 12, 2013). Means followed by the same letter do not differ ( $>0.05)$.

Table 2. Precipitation and climatogical normal ( $\mathrm{mm}$ ) during the experimental period, 2013/2014.

\begin{tabular}{lcccccccc}
\hline Precipitation & \multicolumn{9}{c}{ Month } \\
\cline { 2 - 8 } & Oct/12 & Nov/12 & Dec/12 & Jan/13 & Feb/13 & Mar/13 & Apr/13 \\
\hline Climatological normal & 163.8 & 158.2 & 151.1 & 142.4 & 173.4 & 103.4 & 106.4 \\
Observed precipitation & 257.3 & 47.4 & 289.9 & 133.6 & 138.3 & 307.4 & 181.7 \\
\hline
\end{tabular}

Table 3. Botanical components (Sorghum, Alexandergrass, Senesced material, and other specie) by evaluation period (1: February 8 to March 1, 2013; 2: March 1 to March 22, 2013; and 3: March 22 to April 12, 2013).

\begin{tabular}{lccc} 
& & & \\
\cline { 2 - 4 } & 1 & 2 & 3 \\
& (08-Feb to 01-Mar) & (01-Mar to 22-Mar) & (22-Mar to 12-Apr) \\
\hline Sorghum & $63.35 \mathrm{~A}$ & $30.68 \mathrm{~B}$ & $21.53 \mathrm{~B}$ \\
Alexandergrass & $17.91 \mathrm{~B}$ & $47.80 \mathrm{~A}$ & $52.73 \mathrm{~A}$ \\
Senesced material & 16.68 & 16.35 & 19.43 \\
Other specie & 2.06 & 5.16 & 6.3 \\
\hline
\end{tabular}

Means followed by the same letter within a row do not differ (Tukey's test, $\mathrm{P}<0.05)$. 


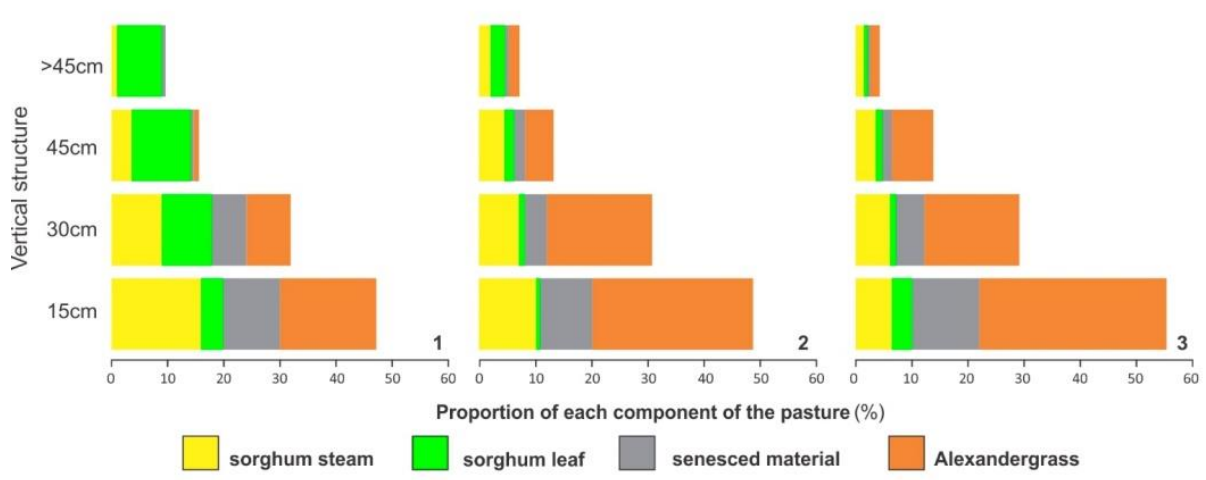

Fig 2. Vertical structure of the pasture (sorghum stem, sorghum leaf, senesced material and Alexandergrass) by evaluation period (1: February 8 to March 1, 2013; 2: March 1 to March 22, 2013; and 3: March 22 to April 12, 2013).
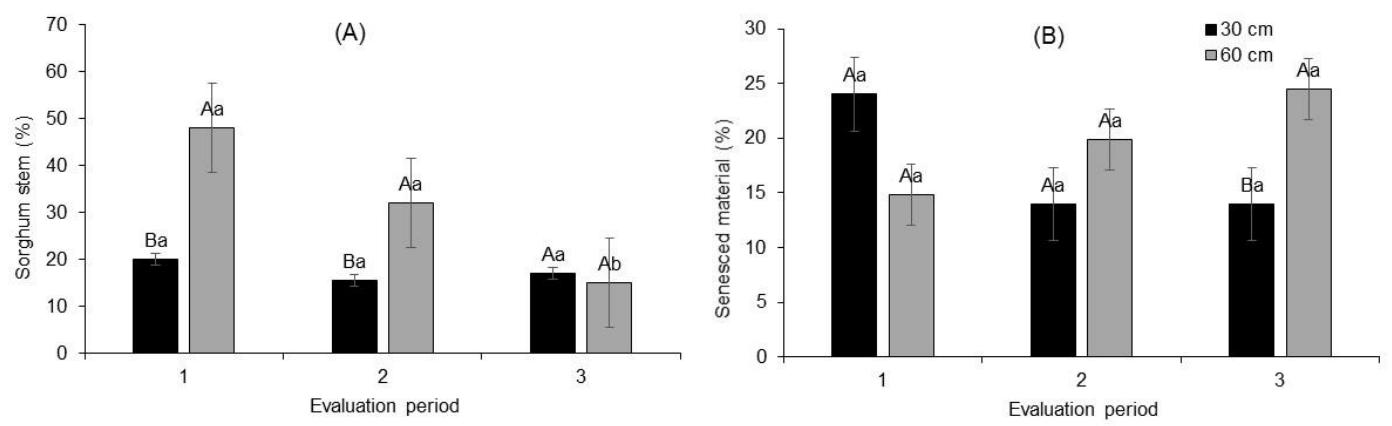

Fig 3. Sorghum stem proportion (A) and senesced material $(B)$ by evaluation periods (EP) and sward heights $(H)$. Means followed by the same capital letter do not differ within EP; means followed by the same lowercase letter do not differ within $\mathrm{H}$ (Tukey's test, $\mathrm{P}<0.05)$. Evaluation periods were: (1: February 8 to March 1, 2013; 2: March 1 to March 22, 2013; and 3: March 22 to April 12, 2013)

Table 4. Dry matter (DM), crude protein (CP), neutral detergent fiber (NDF), acid detergent fiber (ADF), lignin, hemicellulose, and cellulose content (\%) in hand-plucked samples by evaluation periods

\begin{tabular}{lccc} 
& \multicolumn{3}{c}{ Evaluation Period } \\
\cline { 2 - 4 } & 1 & 2 & 3 \\
DM & (February 8 to March 1) & (March 1 to March 22) & (March 22 to April 12) \\
CP & $16.87 \mathrm{~A}$ & $15.38 \mathrm{AB}$ & $13.58 \mathrm{~B}$ \\
NDF & 19.07 & 17.90 & 17.52 \\
ADF & $64.28 \mathrm{~A}$ & $60.36 \mathrm{AB}$ & $57.73 \mathrm{~B}$ \\
Lignin & 32.15 & 30.86 & 30.61 \\
Hemicellulose & $5.42 \mathrm{~A}$ & $5.52 \mathrm{~A}$ & $3.58 \mathrm{~B}$ \\
Cellulose & $32.13 \mathrm{~A}$ & $29.75 \mathrm{AB}$ & $26.87 \mathrm{~B}$ \\
\hline Means followed by the same letter within a row do not differ (Tukey's test, P<0.05) & 25.09 & 27.28 \\
\end{tabular}

(2014) observed that, in tropical pastures, high intake rates occur when animals graze swards with plenty and reachable (higher sward strata) leaf material. Leaf density for sorghum was the highest in the first period of evaluation (Fig. 2). Nevertheless, with higher swards heights, we observed a lower bulk density in the sward of all components, this information is corroborated by Souza et al. (2011).

Starting on period two, sorghum stem and leaf participation decreased noticeably, increasing the share of AG in the pasture. At the beginning of the study, AG was at the bottom layers (0-15 and $15-30 \mathrm{~cm}$ ) and the sorghum leaves increased its participation in the overall pasture. The data on Fig. 2 demonstrates that Alexandergrass was the dominant species in the last measurement event.

Changes in sward structures can be elucidated when the evaluation period $x$ grazing height interaction is analyzed (Fig. 3a and $3 b)$. Sorghum stem presence was kept higher $(P<0.05)$ when the sward was managed higher in the first and second period but reduced in the third $(P<0.05)$. Within the lower height treatment $(30 \mathrm{~cm})$, stem presence did not differ with evaluation 
periods. The significant reduction of canopy height in the third evaluation period was a consequence of senesced sorghum plants and $A G$ prevalence in the sward. This time, there was less senesced material in the $30 \mathrm{~cm}$ than in the $60 \mathrm{~cm}$ sward $(P<0.05)$. Within the $30 \mathrm{~cm}$, it is possible to notice a trend: senesced material decreased with evaluation periods, whereas the opposite holds true for the $60 \mathrm{~cm}$ treatment. AG presence is pointed as the cause for this phenomenon.

\section{Nutritive value}

Accumulation of fiber and lowering crude protein contents are consequences of tropical forage growth (Van Soest, 1994). The resultant depressed animal performance is then a consequence of such processes which include new cellular wall growth and thickening (Mertens, 1993). The diminished CP or nitrogen concentration in the sward follows a pattern of attenuation from the top to the bottom layers (Pons and Percy, 1994). Accumulation of structural and storage tissues that are low in $\mathrm{N}$ content also contributes to the exposed above (Mertens, 1993). Controversially, in this study, the chemical composition of the pasture was seen constant. CP, ADF and cellulose did not vary with evaluation period nor $\mathrm{N}$-fertilization levels. NDF behaved in an unexpected way, having its lowest values at later evaluation periods. There was also significant reduction in DM, hemicellulose and lignin with time (Table 4).

Supporting previous studies (Souza et al., 2011; Pacheco et al., 2014) suggest that maintaining a nutritive and productive pasture can be achieved through addition of new species that were once perceived and managed as weed in grain production systems. We found that AG served as a complementary species to sorghum pasture because it can extend the grazing period of the mixture.

The growth pattern of the Sorghum plus AG pasture was analogous to the one found by Souza et al. (2011) when looking at grazing behavior of beef heifers in a pearl millet $x$ alexandergrass mixture grazed at $40 \mathrm{~cm}$. The authors found that both species had similar chemical and structural composition, which did not impact ingestive behavior. Several publications point $A G$ as a viable alternative on animal production systems since it keeps its productivity until early Fall when temperature starts to decrease (Martins et al., 2000; Restle et al., 2002; Sartor et al., 2011; Costa et al., 2011; Menezes et al., 2014). Nitrogen fertilization on tropical pastures enhance forage production. However, depending on cut regime it can increase lignin deposition on the cell wall of the plants (Van Soest, 1994). In the second evaluation period, there was higher forage accumulation rate. The increased stocking rate of animals onto paddocks may have enhanced defoliation frequency, keeping younger tissues in the sward. Therefore, no difference in lignin content was observed. In the third evaluation period, when vegetative period of growth of sorghum plants was finished, lignin content was similar, either for sward heights or nitrogen levels. That difference cannot be explained by highest AG high quality forage in the sward.

Volunteer AG grew mainly from the sorghum planting line, and not from the between-lines space ("row space"). As a consequence, when the sward was kept at $30 \mathrm{~cm}$, opportunity was greater for $A G$ to thrive since light reached the soil and stimulated AG germination from the seedbank. It is emphasized that $A G$ was the main forage in the pasture during the latter periods of the study. It fed animals in April, when the study region is known to go through a forage shortage. Even though the study was finished in April 12, 2013 due to a waning sorghum crop, the remaining pasture would be able to sustain $1,244 \mathrm{~kg}$ live weight ha-1.

Extending the forage resource usage period in crop-livestock systems is desirable because it increases the system profitability and maximizes the soil use. It is suggested that until there is no cultivar registration for Alexandergrass by the appropriate department in Brazil (National Register of cultivars of the Ministry of Agriculture, Livestock and Supply), a seedbank should be managed to produce for the following year.

\section{Materials and Methods}

\section{Site description}

This study was carried out in Abelardo Luz (26031'S, 51935'W, $850 \mathrm{~m}$ a.s.I.), Santa Catarina, Brazil, from October, 2012 to April, 2013. The climate is $\mathrm{Cfb}$, according to the Köppen classification (Alvares et al., 2014), with well-distributed precipitation throughout the year and mild summers. Climatic data of the experimental period were collected from Meteorological Station at Clevelândia, Paraná (Table 1).

The soil at the study site is classified as Oxisoil and clayey in texture. Soil chemical properties at the beginning of the study were: $\mathrm{pH}\left(\mathrm{CaCl}_{2}\right)=4.57$; organic matter $=36.3 \mathrm{~g} \mathrm{dm}^{-3} ; \mathrm{P}=4.57$ $\mathrm{mg} \mathrm{dm}{ }^{-3} ; \mathrm{K}=87.87 \mathrm{mg} \mathrm{dm}^{-3} ; \mathrm{Ca}=3.85 \mathrm{cmol}_{(\mathrm{c})} \mathrm{dm}^{-3} ; \mathrm{Mg}=1.97$ $\mathrm{cmol}_{(\mathrm{c})} \mathrm{dm}^{-3}$; base saturation $=55.95 \%$.

\section{Experimental design and treatments}

The experiment was performed in a site with a total area of 24 hectares, arranged on a $2 \times 2$ factorial experiment at randomized complete block design with three replicates (paddocks). The treatments were the combination of two sward grazing heights $(30$ and $60 \mathrm{~cm}$ ) and two nitrogen fertilization levels ( 0 and 200 kg N ha-1) in Sorghum-Alexandergrass mixed pasture, grazed by beef cattle.

\section{Conduction of study}

The experimental site was maintained under a crop-livestock system management during previous years. During the winter Avena strigosa ("black oat") was sown and grazed. During the summer grain crops corn, soybeans and pinto beans were cultivated. The area was always kept under no-tillage practices. The cover crops in experimental site were desiccated with glyphosate on October 15, 2012 (900 g of active ingredient per ha). Sorghum planting was finished on November 7, 2012, under no-tillage with a multipurpose seed sowing and planting machine. The ADV2800 hybrid was used and a population of 450,000 plants ha-1 targeted. The volunteer AG plants (Urochloa plantaginea) was obtained from the soil seed bank. During the previous year, in order to guarantee that the seedbank was sufficient, AG pasture was managed at high forage allowance to produce seeds. 
Fertilization at sowing followed the guidelines from the Brazilian Commission for Chemical and Soil Fertility (Cqfs/RS-SC, 2004), considering the results from soil analysis conducted just prior to the experiment. A total quantity of $530 \mathrm{~kg}$ of NPK fertilizer (0820-20) was used, which corresponds to $42.4 \mathrm{~kg} \mathrm{~N} \mathrm{ha}^{-1}, 106 \mathrm{~kg}$ $\mathrm{P}_{2} \mathrm{O}_{5} \mathrm{ha}^{-1}$ and $106 \mathrm{~kg}$ of $\mathrm{K}_{2} \mathrm{O}$ ha $^{-1}$.

In order to set the treatments heights, a grazing session was performed on December 20, 2012. The pre-grazing height was approximately $90 \mathrm{~cm}$. After this grazing period, the sward height was standardized in the plots (paddocks) with a mechanical cut at $50 \mathrm{~cm}$ above the soil. Afterwards, nitrogen top dressing using $200 \mathrm{~kg} \mathrm{~N} \mathrm{ha}^{-1}$ (urea 45\% N) was added and grazers allocated out of the experimental site.

Evaluation period comprised of 65 days, from February 8 to April 12,2013 . Data was collected in three periods (1: February 8 to March 1, 2013; 2: March 1 to March 22, 2013; and 3: March 22 to April 12, 2013).

The put-and-take stocking method was used (Mott and Lucas, 1952) and Nellore by Charolais crossbred steers ( $319 \mathrm{~kg}, \mathrm{SE}=34$ $\mathrm{kg}$ ) served as grazing animals. Each experimental unit (plot) had three tester animals and a variable number of animals to assure that sward height targets were reached. Every 21 days animals were fasted for 12 hours and weighed to stocking rate adjustment. The delta between the targeted and the observed sward height dictated the addition or removal of animals from a plot.

\section{Traits measured}

The grazing heights were measured in 60 random points on plots every three days, using a meter stick. The observations were recorded to the nearest centimeter. Canopy height was defined as the distance between the top soil layer and the average sward height around the stick.

Forage mass ( $\mathrm{kg} \mathrm{DM} \mathrm{ha}^{-1}$ ) was estimated every 21 days through three representative samples from each plot. Forage sample delimited by a metal frame $\left(0.25 \mathrm{~m}^{2}\right)$ and were clipped above the ground level $(0 \mathrm{~cm})$. The samples were weighed, dried at $55^{\circ} \mathrm{C}$ in a forced-air oven to constant weight, and weighed again. The evaluation of morphological components in each vertical layer was performed from two samples collected per plot in each evaluation period. Forage samples were cut from the ground level $(0 \mathrm{~cm})$ in an area delimited with a metal frame $\left(0.405 \mathrm{~m}^{2}\right)$. For every layer $(15 \mathrm{~cm})$, morphological components were manually separated [sorghum leaf lamina, sorghum stem (sheath + stem), senesced material and AG] and dried at 55ㅇ in a forced-air oven to constant weight and weighed. The components were expressed as a proportion of total forage mass (\%).

Samples for nutritive value of forage were hand-plucked from each experimental unit according to methodology suggested by Johnson (1978). We replicated the material gathered in a graze bite through a hand-plucked sample by observing the grazing behavior of the animal. Only one observer took the samples in order to avoid person-to-person bias when performing. Grazing simulation was done by walking zigzag in the plot to choose feeding stations, where a sample was taken. One composed sample per plot per evaluation period was used. In the laboratory, samples were dried at 55으 in a forced-air oven for
72 hours and ground. Subsequently, the composite sample was analyzed for crude protein (CP) according to the micro-Kjedahl method (AOAC, 1984), neutral detergent fiber (NDF), acid detergent fiber (ADF) and lignin according to Van Soest et al. (1991).

\section{Statistical analysis}

Data was analyzed using the MIXED procedure of SAS software (version 9.0, SAS Institute Inc.). Evaluation period was used as a repeated measure in time with $5 \%$ significance according to the Kenwardroger method (Gutzwiller and Riffel, 2007). Rates were separated based on Tukey's test at 5\% significance.

\section{Conclusion}

Nitrogen fertilization and grazing height do not affect sorghum $x$ alexandergrass mixed pastures structural components and quality. The addition of alexandergrass to a sorghum pasture can extend the grazing period into the fall keeping favorable sward structure and its nutritive value to livestock production.

\section{Acknowledgments}

We are grateful for the Improvement of higher Education Personnel/Postdoctoral National Program (CAPES/PNPD) for supporting this study.

\section{References}

Adami PF, Soares AB, Assmann TS, Assmann AL, Sartor LR, Pitta CSR, Franchin MF (2010) Dynamic of papuã pasture under two grazing intensities and two nitrogen levels. Rev Bras Zootec. 39: 2569-2577.

Alvares CA, Stape JL, Sentelhas PC, Gonçalves JLM, Sparovek G (2014) Koppen's climate classification map for Brazil. Meteorol Zeitschrift. 22:711-728.

Aoac International (1984) Official methods for analysis. $14^{\text {th }}$ edn. Aoac International, Arlington.

1108.

Costa VG, Rocha MG, Pötter L, Roso D, Rosa ATN, Reis J (2011) Comportamento de pastejo e ingestão de forragem por novilhas de corte em pastagens de milheto e papuã. Rev Bras Zootec. 40: 251-259.

Sbcs/Cqfs - Sociedade Brasileira de Ciência do Solo - Comissão de Química e Fertilidade do Solo (2004) Manual de adubação e de calagem para os Estados do Rio Grande do Sul e Santa Catarina. $10^{\text {th }}$ edn. Sbcs - Cqfs, Porto Alegre.

Gutzwiller K, Riffel SK (2007) Using statistical models to study temporal dynamics of animal-landscape relations. In: Bissonete JA, Storch I (ed.) Temporal dimensions of landscape ecology - Wildlife responses to variable resources, $1^{\text {st }}$ edn. Springer, Boston.

Johnson AD (1978) Sample preparation and chemical analysis of vegetation. In: Manetje Lt' (ed.) Measurement of grassland vegetation and animal production. $1^{\text {st }}$ edn. Farnham Royal.

Martins JD, Restle J, Barreto IL (2000) Produção animal em capim papuã (Brachiaria plantaginea (Link) Hitchc) submetido a níveis de nitrogênio. Cienc Rural. 30: 887-892. 
Martini PM, Brondani IL, Alves Filho DC, Viana AFP, Adams SM, Klein JL, Rodrigues LS, Cattelam J (2017) Comportamento ingestivo de bovinos jovens mantidos em pasto de sorgo ou milheto. Bol Ind Anim. 74: 308-318.

Menezes LFG, Segabinazzi LR, Freitas LS, Restle J, Brondani IL, Callegro AM, Joner G, Alves Filho DC (2014) Aspectos qualitativos da carcaça e carne de novilhos superjovens da raça Devon, terminados em pastagem tropical, recebendo diferentes níveis de concentrado. Semin-Cienc Agrar. 35: 1557-1568.

Mertens DR (1993) Kinetics of cell wall digestion and passage in ruminants. In: Jung HG, Buxton DR, Hatfield RD (ed) Forage cell wall structure and digestibility. $1^{\text {st }}$ edn. American Society of Agronomy, Madison.

Mezzalira JC, Carvalho PCF, Fonseca L, Bremm C, Cangiano C, Gonda HL, Laca EA (2014) Behavioural mechanisms of intake rate by heifers grazing swards of contrasting structures. Appl Anim Behaviour Science. 153: 1-9.

Mott GO, Lucas HL (1952) The design, conduct, and interpretation of grazing trials on cultivated and improved pastures. In: $6^{\text {th }}$ International Grassland Congress, State College Press, Pennsylvania, 1956.

Pacheco RF, Alves Filho DC, Brondani IL, Nörnberg JL, Pizzuti LAD, Callegaro AM (2014) Características produtivas de pastagens de milheto ou capim sudão submetidas ao pastejo contínuo de vacas para abate. Cien Anim Bras. 15: 266-276.

Pons TL, Pearcy RW (1994) Nitrogen reallocation and photosynthetic acclimation in response to partial shading in soybean plants. Physiol Plantarum. 92: 636-644.
Restle J, Roso C, Aita V, Nörnberg JL, Brondani IL, Cerdótes L, Carrilho CO (2002) Produção animal em pastagem com gramíneas de estação quente. Rev Bras Zootec. 31: 14911500.

Robson MJ, Ryle GJA, Woledge J (1988) The grass plant - its form and function. In: Jones MB, Lazenbay $A$ (ed) The grass crop: the physiological basis of production. $1^{\text {st }}$ edn. Chapman and Hall, Londres.

Roman, J, Rocha, MG, Genro, TCM, Santos, DT, Freitas, FK, Montagner, DB (2008) Características produtivas e estruturais do milheto e sua relação com o ganho de peso de bezerras sob suplementação alimentar. Rev Bras Zootec. 37: 205-211.

Oliveira JR, Soares AB, Adami PF, Glienke CL, Balbinot Jr. AA (2018) Corn and Alexander grass intercropping system: Influences of herbicide management on grain and forage yield. Colloq Agrariae. 25: 66-72.

Sartor LR, Assmann TS, Soares AB, Adami PF, Assmann AL, Pitta CSR (2011) Nitrogen fertilizer use efficiency, recovery and leaching of an Alexander grass pasture. Rev Bras Cienc Solo. 35: 899-906.

Souza AM, Rocha MG, Pötter L, Roso D, Glienke CL, Oliveira Neto RA (2011) Comportamento ingestivo de novilhas de corte em pastagem de gramíneas anuais de estação quente. Rev Bras Zootec. 40: 1662-1670.

Van Soest PJ, Roberston JB, Lewis BA (1991) Methods for dietary, fiber neutral detergent fiber and nonstarch polysaccharides in relation to animal nutrition. J Dairy Sci. 74: 3583-3597.

Van Soest PJ (1994) Nutritional ecology of the ruminant. $2^{\text {nd }}$ edn. Cornell University, New York. 